\title{
La fotografía como documento sociocultural a finales del siglo XIX: Nadar y el retrato post mórtem
}

\author{
Photography as Sociocultural Document in late \\ Nineteenth-Century: Nadar and Postmortem Portrait
}

\author{
José Fernando Vázquez Casillas \\ Departamento de Historia del Arte \\ Facultad de Letras. Universidad de Murcia
}

\section{RESUMEN}

No cabe duda de que la fotografía se posicionó en el siglo XIX como el elemento trascendental que democratizó definitivamente el retrato. La ciudadanía halló en este procedimiento el medio más eficaz para su representación social. En este sentido, planteamos en este artículo el importante papel que va a desempeñar la fotografía como documento sociocultural a finales del siglo XIX a través del estudio ideológico del retrato post mórtem como una modalidad usual en el ámbito familiar de aquel tiempo. Para la comprensión de esta iconografía tomamos como referente las reflexiones del fotógrafo y teórico Gaspard-Félix Tournachon "Nadar", con el fin de profundizar tanto en la función social del retrato de difuntos como en su posicionamiento dentro de la práctica fotográfica.

Palabras clave: Fotografía post mórtem, Retrato, Siglo XIX, Gaspard-Félix Tournachon "Nadar".

\section{SUMMARY}

There is no doubt that photography was a transcendental element in nineteenth-century that definitely democratized portraiture. Citizenship found in this procedure the most effective way for their social representation. In this sense, this article deals with the important role photography played as as sociocultural document in late nineteenth-century through post mortem portrait studio. To understand this iconography we take as reference to Gaspard-Félix Tournachon "Nadar" testimony. The reflections of this photographer and theorist will help to clarify the social role of post mortem portrait at that time.

Key words: Post Mortem Photography, Portrait, XIX ${ }^{\text {th }}$ Century, Gaspard-Félix Tournachon "Nadar".

En la Europa del siglo XIX el retrato se convirtió en el género protagonista de la pintura, encarnando la expresión máxima de la transformación del gusto y la mentalidad de una nueva clientela, surgida entre la nobleza y la alta burguesía adinerada. Esta emergente clase social, junto con las ya establecidas, encargará multitud de retratos destinados a la decoración de sus residencias privadas como reflejo del valor de lo individual en la nueva sociedad. 


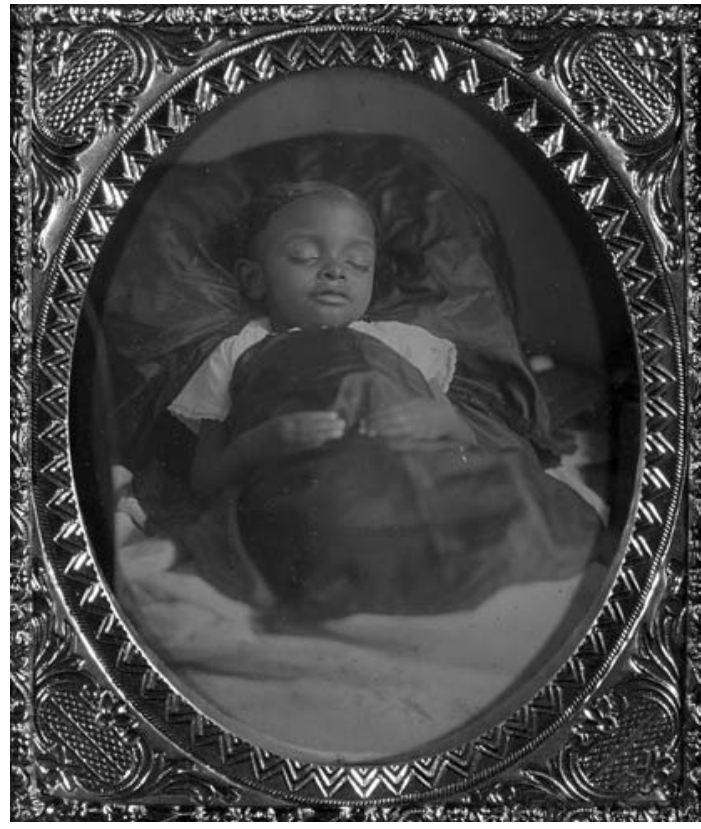

FIgURA 1.-Anónima. Retrato post mórtem de un bebé. 1855. J. Paul Getty Museum.

La exclusividad de este género, distintivo de claro prestigio social, convivirá a partir de 1839 con los retratos fotográficos que, al igual que los pictóricos, emergerán como una muestra evidente de la posición social de su propietario, al tiempo que lograban perpetuar la memoria viva de la imagen del representado para la posteridad (Díez 2004: 264).

A finales del siglo XIX las nuevas técnicas fotográficas traerán consigo la democratización definitiva del retrato, al menos en lo que al ámbito fotográfico se refiere, así como la aparición de novedades conceptuales, tipológicas e iconográficas que ampliarán sensiblemente los usos y funciones de la fotografía, en un proceso similar al experimentado con la democratización del retrato en el siglo XVI.

Esta universalización de la fotografía permitió la renovación de tipologías clásicas pero exclusivas — como el retrato post mórtem- que, a partir de este momento, gozarán de una amplísima demanda y extensión, dado su estrecho vínculo con algunas de las principales funciones de la fotografía en ese momento.

El retrato post mórtem se convierte en un fenómeno internacional dotado de las peculiaridades que le imprimen las distintas sociedades que lo adoptan en todos los continentes. La fotografía, como cualquier otra obra de arte, debe ser descodificada para ser comprendida. Se presenta como un enunciado incompleto, un mensaje que depende de diversos condicionantes (Sekula 1981: 452)․․ Así pues, y centrándonos en la fotografía de difuntos, planteamos un proceso de análisis con el fin de focalizar nuestra atención en las funciones socioculturales de este género. El teórico Jean Ruby, cuando comenzó en el último cuarto del siglo XX su investigación etnográfica sobre el cometido sociocultural de la fotografía en un condado rural de Pensilvania, descubrió casi por azar que era común en esa zona la representación post mórtem. Al sentir

\footnotetext{
${ }^{1}$ En este mismo sentido, son de gran interés las apreciaciones de Javier Marzal cuando expone: "Sin duda, una de las limitaciones metodológicas y teóricas que padece la historia de la fotografía es la 'estrechez de miras', fragmentariedad y falta de capacidad para la articulación de interpretaciones históricas que impliquen el marco general de la historia del arte, la historia de los medios de masas y la historia económica y social. Creemos necesario que el estudio de la fotografía se despliegue a través del examen riguroso de las condiciones de producción, condiciones de recepción y del propio estudio de la materialidad de la obra fotográfica, una propuesta que está en el marco de una concepción general de la historia del arte y de la comunicación [...]" (Marzal Felici 2011: 39).
} 
la necesidad de ampliar su estudio, comprobó que no se limitaba a un territorio rural con un componente étnico determinado, sino que se trataba de un acto común en diferentes niveles sociales (Ruby 1995). De este modo, deconstruía las conclusiones reduccionistas de Michael Lesy (1973), quien había afirmado que la fotografía de difuntos era una costumbre victoriana extraña que se convirtió prácticamente en un hecho inexistente e irrelevante, limitado a algunos enclaves étnicos.

Nada más lejos de la realidad, puesto que la fotografía post mórtem supone un común denominador para diferentes culturas del mundo: una necesidad de retener al ser querido, de mantener en el plano bidimensional la vida ya desaparecida del fallecido, que no conoce fronteras geográficas pero sí distintos modos de entender el concepto de la imagen. Hablamos, por consiguiente, de un ejercicio plural, con unas iconogra-

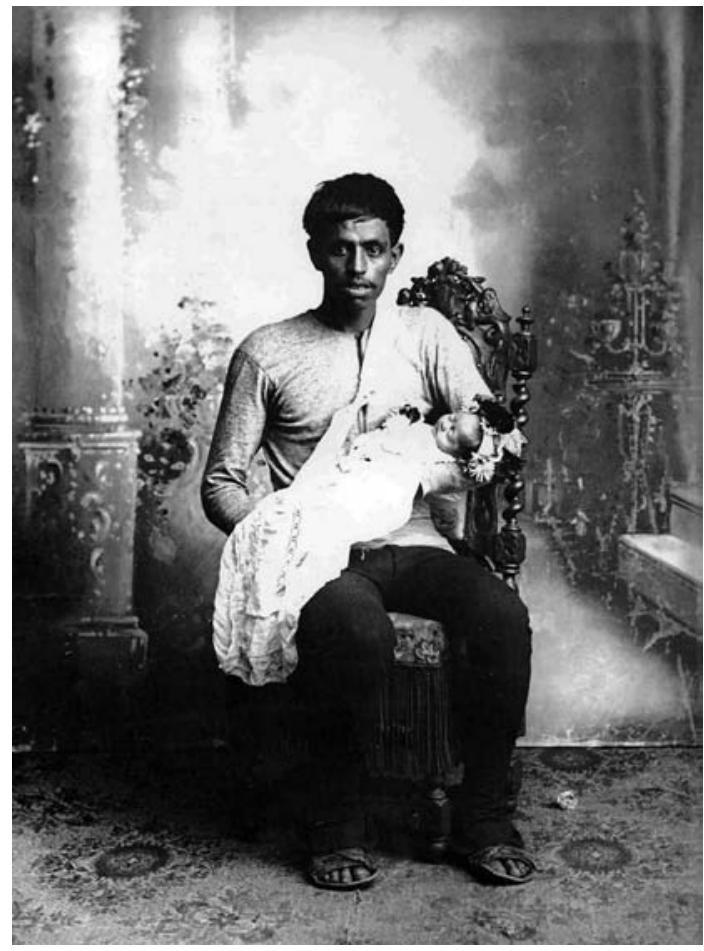

FIgura 2.--Romualdo García. Retrato de padre y niño difunto. Segunda mitad del siglo XIX. Col. Colmich. fías básicas modificadas por las necesidades de cada lugar de las que se derivan distintas interpretaciones (fig. 1). Estas iconografías serán más o menos elaboradas en función de las exigencias del demandante y de la intención de la familia al encargar la fotografía (Kershner 1999: 273). Es decir, dependerán de los usos y funciones atribuidas a estos retratos. Así, mientras que en Norteamérica se hace común la representación de los niños con objetos que les caracterizan, como juguetes o ropas determinadas —identificativas del individuo-, en las escenificaciones centroamericanas a las niñas se las representa amortajadas como la Inmaculada y a los niños como San José o el Sagrado Corazón ${ }^{2}$ (fig. 2).

De lo expuesto hasta ahora se deduce que nos encontramos ante imágenes que conmemoran historias particulares, siendo de gran importancia aquellas que, aun crea-

${ }^{2}$ Las imágenes post mórtem de niños producidas en Sudamérica son producto tanto de la demanda familiar como de un profundo ritual que sobrepasa el propio hecho fotográfico. En este sentido, la muerte de un niño siempre ha estado sujeta a ciertos rituales desde la antigüedad. En el asunto que nos ocupa, la presencia de conceptos marianos es evidente, en muchos casos, tanto en el propio ritual o vestimenta como en el acto conceptual. En este sentido, el niño muerto, como ser puro según la creencia católica, se convierte directamente en un angelito, aun no estando bautizado, y al igual que la Virgen es un ser mediador con la muerte y el paraíso. Además, en las representaciones de estos "angelitos" se emplean recursos simbólicos similares a los utilizados para la Virgen: coronas o palmas (Álvarez 1998: 380). 
das en un marco personal, conquistan un lugar trascendente en su contexto cultural e histórico (Sturken 1999: 178-179). En este caso, hacemos referencia a narraciones íntimas, a microhistorias familiares que componen una historia global, en las que el recuerdo es la base primaria de su existencia. Se trata de retratos que presentan una problemática común de análisis y deben ser estudiados como cualquier obra de la historia del arte, es decir como un hecho cultural y sin ser extraídos de su entorno, tiempo e ideología. Muchas de estas producciones son descontextualizadas en su proceso de investigación y pierden su significado inicial, lo que genera, en el mejor de los casos, un nuevo sentido ligado ya no a la remembranza del representado sino a la conservación de una iconografía de la historia de la fotografía.

Desde el propio desarrollo del daguerrotipo se inició este tipo de composiciones, puesto que se adecuaba perfectamente a las nuevas exigencias de la sociedad de la época ${ }^{3}$. De este modo, el 14 de octubre de 1839 ya se menciona en la Academia de las Ciencias de París, a través de una carta del doctor Alfred Donné, el uso de esta modalidad fotográfica: "He obtenido ya un resultado muy bello tomando la imagen de una persona muerta [...]" (Bolloch 2002: 112-113). El propio Hypolite Bayard, en octubre de 1840, efectúa un autorretrato en el que se muestra como ahogado. Aunque se trata de una reivindicación ante el olvido de sus aportaciones al procedimiento fotográfico, lo interesante es que se presenta como uno de los primeros ensayos de una imagen post mórtem (Kennel 2007: 123). En el dorso de la imagen incluyó una leyenda que rezaba: "El cadáver que usted ve aquí es el de M. Bayard, inventor del proceso que acaba de ser mostrado a usted ${ }^{4}$. Tal será la demanda de este tipo de imágenes que llegarán a ser algo banal, incluso vulgar, no solo por el gran núme-

\footnotetext{
${ }^{3}$ En este sentido, la democratización que propicia la imagen fotográfica hace posible la presencia de todos, o gran parte, de los sectores de la sociedad. Una parte de los que por su posición social habían sido discriminados dentro de la representación de sí mismos encuentran desde 1840 su espacio, ya sean campesinos en el caso de Europa, ya sean marginados por su color de piel en el caso de Norteamérica. Todos formarán parte de una historia, de su historia. Es un momento importante para la presencia de todos, o casi todos, en el mundo — el hombre del XIX se ve a sí mismo como actor y parte principal del nuevo escenario-. El procedimiento fotográfico asume el sueño de la existencia eterna, del recuerdo que se perpetúa en el tiempo como memoria social, una memoria amplia y varia. Así pues, el mismo año de la presentación del daguerrotipo al mundo, en 1839, autores como John W. Draper o Robert Cornelius realizan ya los primeros retratos con éxito de la historia de la fotografía - aun siendo un procedimiento primario que evolucionará tremendamente en su simplificación y eficacia-(Johnson 1999: 100). John W. Draper incluso llega a publicar en 1840 un texto dedicado a las aplicaciones del procedimiento al retrato, ofreciendo ya en esos primeros tiempos pautas para los mejores resultados de este género (Draper 1840: 217-225).

4 "The corpse which you see here is that of M. Bayard, inventor of the process that has just been shown to you. As far as I know, this indefatigable experimenter has been occupied for about three years with perfecting his discovery... All those who have seen his pictures admired them as you do at this very moment, although he considers them still imperfect. This has brought him honor, but not a single penny. The Government, which has been only too generous to Monsieur Daguerre, says it can do nothing for Monsieur Bayard, and the unhappy wretch has drowned himself in despair. Oh human fickleness! For some time, artists, scientists and the press took an interest in him, but now that he has been at the morgue for several days, nobody has recognized him. Ladies and gentlemen, let us discuss something else so as not to offend your sense of smell, for as you can see, the face and hands of the gentleman are already beginning to decay" (Gautrand y Frizot 1986: 221).
} 
ro de imágenes realizadas, sino también por el uso repetitivo de ciertas iconografías. Esta trivialización posibilita que sea común su presencia (como la de cualquier otro ejemplo de retrato del siglo XIX) dentro de la publicidad de los estudios de fotografía de la época (Cuarterolo 2002: 26) y en los artículos de opinión de la prensa diaria. En estos se proporcionan los pasos adecuados a seguir para realizar trabajos correctos, dando consejos de actuación sobre el difunto y el espacio para conseguir los mejores resultados (Burgess 1855: 80). A todo ello se suma la mención, en la trasera de las fotografías, de la realización de imágenes mortuorias entre los méritos del autor, lo cual enfatiza aún más lo usual de este tipo de encargos 5 .

Evidentemente, se convierte en una labor habitual para gran parte de los fotógrafos, tanto para los de los grandes estudios de las capitales como para los más modestos de provincias. Así, desde 1841 es ya una actividad frecuente al adecuarse perfectamente a las posibilidades técnicas de la época (Creekmur 1996: 74), las cuales requerían largos tiempos de exposición por lo que, en el caso de los retratos, el sujeto debía permanecer inmóvil. A todo lo anteriormente expuesto se ha de añadir la asimilación del concepto de la muerte como algo cercano, como un acontecimiento que formaba parte de la vida, siempre presente e inevitable, por encima del control humano (O'Connor 2005).

En este contexto, la fotografía post mórtem viene a cubrir, de forma genérica, varios propósitos socioculturales, de entre los que destaca su capacidad de consuelo para con los afligidos. La imagen se convertía, así, en un objeto de gran valor por su carácter documental y representativo ya que, además de como recuerdo en un álbum fotográfico, servía también como elemento a compartir entre los familiares que no habían estado presentes en el funeral, erigiéndose en testigo notarial de los detalles del deceso del ser querido. Esta fotografía se convierte en representación tangible de la persona que ha fallecido, algo especialmente importante cuando la imagen póstuma era la única existente del individuo ${ }^{6}$.

Como hemos señalado anteriormente, el origen de este tipo de producciones en su gran mayoría está ligado al consumo familiar ${ }^{7}$, lo que motivaba su presencia en los espacios destinados para la exhibición privada de las imágenes del clan, ya fue-

${ }^{5}$ En España hallamos ejemplos como la publicidad trasera del estudio Napoleón de la ciudad de Barcelona, la cual, en 1855, entre otros importantes datos informativos incluía el de que se fotografiaba difuntos a domicilio (García Felguera 2011: 22).

${ }^{6}$ Algunos fotógrafos tendrán como especialidad las representaciones post mórtem infantiles. Es el caso de autores como Cristiano Junior que, asentado en Buenos Aires entre 1867 y 1878, realizará un importante número de imágenes de niños y bebés difuntos. Actividad que él mismo llega a anunciar en la trasera de sus cartones como una de sus habilidades (Guerra 2010: 107).

${ }^{7}$ Esta imagen perpetúa para siempre la existencia del ser desaparecido. En este sentido, afirma Stanley B. Burns que la imagen mortuoria en los Estados Unidos se dedica preferentemente a expresar la pérdida personal de un allegado, mientras que la realizada en Europa, aunque posee el mismo significado que la norteamericana, alcanza otros tipos de representación puesto que abundan también las imágenes post mórtem de personajes de la realeza, de la nobleza, etc. (Burns 2002: s/p.). Estos retratos post mórtem de individuos famosos también forman una pequeña minoría del comercio del retrato fotográfico. En este sentido, era común poder comprarlos en tiendas de artículos de lujo, papelerías y estudios fotográficos. Solían ser retratos tomados después del fallecimiento de jefes de Estado, héroes militares y líderes religiosos, así como de personas con una reputación excepcional en las ciencias y las artes (Linkman 2012: 19). 
ran mesas, chimeneas, paredes o álbumes ${ }^{8}$. Se trata, por lo tanto, de un material que debe ser interpretado, casi en su totalidad, como objetos privados de uso íntimo', ya que, de hecho, en muchas ocasiones es más un objeto de culto que un elemento meramente fotográfico. No debemos olvidar que este tipo de retratos se convierte en una fórmula, en cierto modo, de alivio de los vivos frente al trágico trance (Linkman 2006: 311). La fotografía, por lo tanto, ejerce como un moderno proceso de momificación del individuo para la eternidad y se convierte en una presencia perenne mientras la imagen exista, lo que posibilita a los dolientes la meditación sobre el difunto (Cadwallader 2008: 16). Nos encontramos, pues, ante un instrumento de transición: un objeto a través del que contactar con el ser querido ausente.

En general, se trata de imágenes usadas para documentar una presencia, totalmente distintas a aquellas que documentan una muerte, como puede ser un linchamiento (Campbell 2004: 55-74) o un asesinato legal. Así, tenemos un elemento sustitutivo del fallecido, un recuerdo imperecedero del mismo, que el grupo empleará como pieza clave y precisa frente al fin de la vida y la fugacidad de esta. En este sentido, algunos autores las estudian, más allá de la razón primaria de su existencia, como objetos sociales y humanos, considerándolas como artefactos protésicos o fetiches (Olguin 2010: 100-101), o incluso como imágenes o artilugios idolátricos, conceptos implantados socialmente por esta nueva creación tecnológica que es la fotografía (Mitchell 2005).

Es probable que algunos usos de esta clase de imágenes se puedan adscribir a estas concepciones, pero lo que es innegable es que la fotografía post mórtem viene a cubrir una necesidad, una demanda humana de retención visual del difunto para comodidad de la memoria. Se trata, en definitiva, de recordar, de perpetuar a través de un pequeño objeto al ser querido, siguiendo los preceptos básicos del retrato (Martínez Artero 2004).

\footnotetext{
${ }^{8}$ Apoyada por todas estas inquietudes y por las nuevas demandas sociales, se produce, en un período de desarrollo como es el siglo XIX, una expansión de la imagen sin precedentes en la historia del arte, pasando de la galería de retratos pictóricos para sectores minoritarios al álbum fotográfico asequible para un amplio grupo social. Y es que coleccionar retratos de familiares y de amigos es una costumbre que tiene su origen en el renacimiento europeo, aunque evidentemente de una forma muy elitista, lejos de la liberación que ofrece la fotografía (Falomir 2008: 17-21). Como consecuencia de esta democratización, el álbum de fotografías familiares emergió como una forma social de coleccionismo en la década de 1860. El gran número de imágenes que se acumula en los hogares necesita unas nuevas formas de recopilación y exhibición familiar. En este contexto, los destinatarios de todas estas tarjetas empiezan a organizar en libros personales las diferentes fotografías, formando álbumes que podían mostrar a los visitantes del hogar. Así, la "carta de visita" inaugura un sistema de intercambio de imágenes, de posesión y representación de seres humanos. Con los álbumes se refuerza un sentido de comunidad y pertenencia —además el álbum de fotografías también produce una comunidad imaginaria al situar juntas a personas que nunca han tenido relación unas con otras y que ni siquiera se conocen, creándose nuevos vínculos- (Smith 1998: 101).

${ }^{9}$ Hacemos esta aclaración ya que existen ejemplos interesantes en los que este tipo de imágenes privadas tenía un carácter público, aunque el representado no fuese un personaje destacado de la sociedad del momento (como por ejemplo un gobernante). Uno de estos ejemplos es el retrato del niño May Twiss, imagen post mórtem que forma parte del libro May. 13 Jan. 1859 - 30 May 1865, impreso en 1866 por la firma Kemink Utrecht. Sin duda, el retrato es un encargo de los padres del niño. El libro se compone de fragmentos procedentes de la Biblia y de poetas como Alfred Lord Tennyson y Henry Longfellow, como forma de consuelo familiar frente a la pérdida del ser querido (Krabben 1998: 165; Rooseboom 2011: 94).
} 


\section{NADAR Y EL RETRATO POST MÓRTEM}

Como hemos expresado anteriormente, el retrato post mórtem fue una ocupación general de gran parte de los fotógrafos profesionales de la segunda mitad del siglo XIX, quienes realizaron este tipo de imágenes en algún momento de su producción fotográfica, llegando, incluso, alguno de ellos a convertirlo en su sello de identidad hasta especializarse en esta modalidad de retratos. Es evidente que la gran demanda social de este tipo de obras proporcionó importantes beneficios económicos a los fotógrafos, por lo que, con agrado o desagrado, incorporaron a sus "álbumes muestrario" estas iconografías.

En este contexto nos acercamos a la figura de Gaspard-Félix Tournachon (18201910), "Nadar", uno de los grandes retratistas de la historia de la fotografía que, al igual que otros muchos de su época, cultivó el retrato de difuntos hasta el punto de escribir una serie de consideraciones teóricas sobre este proceder en su texto Cuando yo era un fotógrafo (Tournachon 1900). En este manuscrito, el autor —como afirma Rosalind Krauss - "escribe sus recuerdos con la conciencia del historiador y con esa necesidad irresistible de expresarse que tienen los testigos oculares: todo su texto está lleno de un sentimiento de responsabilidad [...]" (Krauss 2002: 21). Sus pensamientos escritos nos van a presentar al Nadar teórico, al ejecutante que compagina su carrera como uno de los maestros más importantes de la fotografía del siglo XIX con su vertiente reflexiva, modalidad en la que ejerce como historiador, intentando ser testigo de su época (Bann 2009: 97).

El título es un eco de Cuando yo era estudiante (1856), su primer trabajo (Tournachon 1858), libro en el que relata momentos de su juventud (Rouillé 1995: 107); aunque hemos de esperar a 1899 para que Nadar culmine Cuando yo era un fotógrafo, que será publicado en 1900. Cuando el autor escribe el texto cuenta con ochenta años de edad, con lo que ya es un hombre sereno, totalmente desarrollado tanto en su faceta práctica como teórica. El libro se divide en catorce apartados en los que el autor narra de forma novelada y subjetiva relatos que giran en torno a conceptos de la fotografía. Solo uno de los capítulos, "Los primitivos fotógrafos", está planteado como un relato histórico (Cadava 2012: 56-77).

Su experiencia se convirtió en la llave de acceso para calibrar los cambios sociales y culturales que la fotografía estaba ayudando a llevar a cabo en esos momentos, por lo que es una de las obras más interesantes acerca de la fotografía del siglo XIX, escrita a modo de alegoría por un fotógrafo. Prueba de ese interés son los muchos investigadores que se han ocupado de él: por ejemplo, W. Benjamin tendrá en cuenta sus historias, las leerá asiduamente y dejará constancia de su contenido en sus investigaciones (Benjamin 2004: 685-686), completando así la narración de Nadar.

Por otra parte, y de acuerdo con los análisis de distintos investigadores, el libro contiene claramente la idea de la muerte y la relaciona insistentemente con la fotografía $^{10}$. Como afirma Eduardo Cadava, a lo largo de sus relatos hallamos, en diferen-

\footnotetext{
${ }^{10}$ En este sentido, la relación entre la muerte y la fotografía ha sido expuesta de distintas formas por varios estudiosos, insistiendo todos ellos en las conexiones conceptuales entre ambas. Por ejemplo, son interesante para nuestro planteamiento las reflexiones de autores como André Bazin, Walter Benjamin, Roland Barthes o Susan Sontag. Bazin (2006: 23-31) llega a equi-
} 
tes ocasiones, una conexión evidente entre la fotografía y el duelo, entre la fotografía y la muerte. Señala este autor cómo el encuentro de Nadar con lo mortuorio se manifiesta en su persistente fotografiar durante cuatro décadas las ruinas y la muerte como concepto: "aquellas ruinas que son los cuerpos mortales que tan a menudo se sentaron delante de la cámara, hacen que su estudio también puede ser entendido como una cámara mortuoria, algo que él mismo sugiere en sus memorias" (Cadava 2012: 72).

Es evidente que Nadar en sus reflexiones es consciente de que todo pasa, de lo efímero de las cosas y, por lo tanto, de la muerte en sentido abstracto. Tiene muy presente que los objetos, incluso las personas de sus fotografías, están inevitablemente destinadas a la desaparición. Barthes anota en este contexto: "un excelente fotógrafo, un día, me fotografió; creí leer en esa imagen la pesadumbre de un reciente duelo" (Barthes 1999: 47). Así pues, Nadar asocia la fotografía con la muerte y el duelo de una forma precisa, razonada y evidente, lo cual ayuda a explicar por qué su crónica está llena de cadáveres.

Esta asociación es total en el capítulo 8 donde, bajo el título "El secreto profesional" ("Le secret professionnel"), relata una de sus experiencias en la realización de una fotografía post mórtem. El texto comienza con una frase conciliadora: "Seguramente, este había sido muy querido...." ${ }^{11}$. Un enunciado introductorio que intenta suavizar el relato siguiente en el que describe con crudeza verbal una fotografía precisa, un icono modélico, que ejemplifica una imagen común de muchos hogares del siglo XIX: "Estaba tumbado, ya rígido, sobre sábanas blancas de las cuales emergía la parte superior de su cuerpo, alineando los dos brazos sobre la línea doblada " ${ }^{12}$. Una posición concreta que recuerda a cientos de fotografías post mórtem en las que los brazos del difunto quedan al descubierto sobre el cuerpo, rememorando escenografías de yacentes tanto de la disciplina escultórica como de la pictórica. No se trata en este caso de

parar los retratos de los álbumes familiares con las máscaras mortuorias basándose en que la fotografía viene a cumplir la función de la máscara en la época de la reproductividad técnica. Igualmente significativas son las apreciaciones de Benjamin cuando afirma: "No es casual que el retrato esté en el centro de la fotografía más temprana. En el culto al recuerdo de los seres queridos lejanos o difuntos tiene el valor de culto de la imagen su último refugio. En la expresión fugaz de un rostro humano en las fotografías más antiguas destella así por última vez el aura" (Benjamin 2008: 21). Por su lado, Barthes hace continuas alusiones a esta relación en La cámara lúcida y aporta, entre otras, consideraciones como: "Todos esos jóvenes fotógrafos que se agitan por el mundo consagrándose a la captura de la actualidad no saben que son agentes de la Muerte" (Barthes 1999: 160) o también: "En la Fotografía la presencia de la cosa (en cierto momento del pasado) nunca es metafórica; y por lo que respecta a los seres animados, su vida tampoco lo es, salvo cuando se fotografía cadáveres; aún así: si la fotografía se convierte entonces en algo horrible es porque certifica, por decirlo así, que el cadáver es algo viviente, en tanto que cadáver: es la imagen viviente de una cosa muerta" (Ibid.: 139). Por último, e igualmente relacionado con las imágenes de difuntos, apunta Susan Sontag: «Para el paseante solitario, todos los rostros de fotografías estereotípicas ahuecadas tras un vidrio y fijadas en las lápidas de los cementerios de países latinos parecen contener una profecía de sus muertes. Las fotografías declaran la inocencia, la vulnerabilidad de las vidas que se dirigen hacia su propia destrucción, y este vínculo entre la fotografía y la muerte lastra todas las fotografías de personas" (Sontag 2008: 105).

11 "Assurément, celui-là avait été aimé..." (Tournachon 1900: 149).

12 "Il était étendu, déjà rigide, sous les draps blancs dont le haut du corps émergeait, alignant les deux bras sur le linge reverse" (Ibid.). 
una imagen del muerto vivo, sino de su última fotografía, como las que Nadar tomaría de Gustave Doré o Víctor Hugo en su lecho de muerte ${ }^{13}$ (fig. 3). En este sentido, Jay Ruby, en los años noventa del siglo XX, acuñó una serie de términos para referirse a los diferentes modelos iconográficos relacionados con los retratos post mórtem, términos que especifican un tipo de imagen y tiempo de desarrollo: dormido, vivo y muerto (Ruby 1995). La descripción que realiza Nadar encaja evidentemente con el último apartado, en el que el reconocimiento de la muerte es notorio y no se trata de ocultar (en los últimos años del siglo XIX el retratado puede incluso aparecer en su ataúd). Así, se convierte este autor en un narrador preciso, que no omite detalles de una situación compleja y escabrosa.

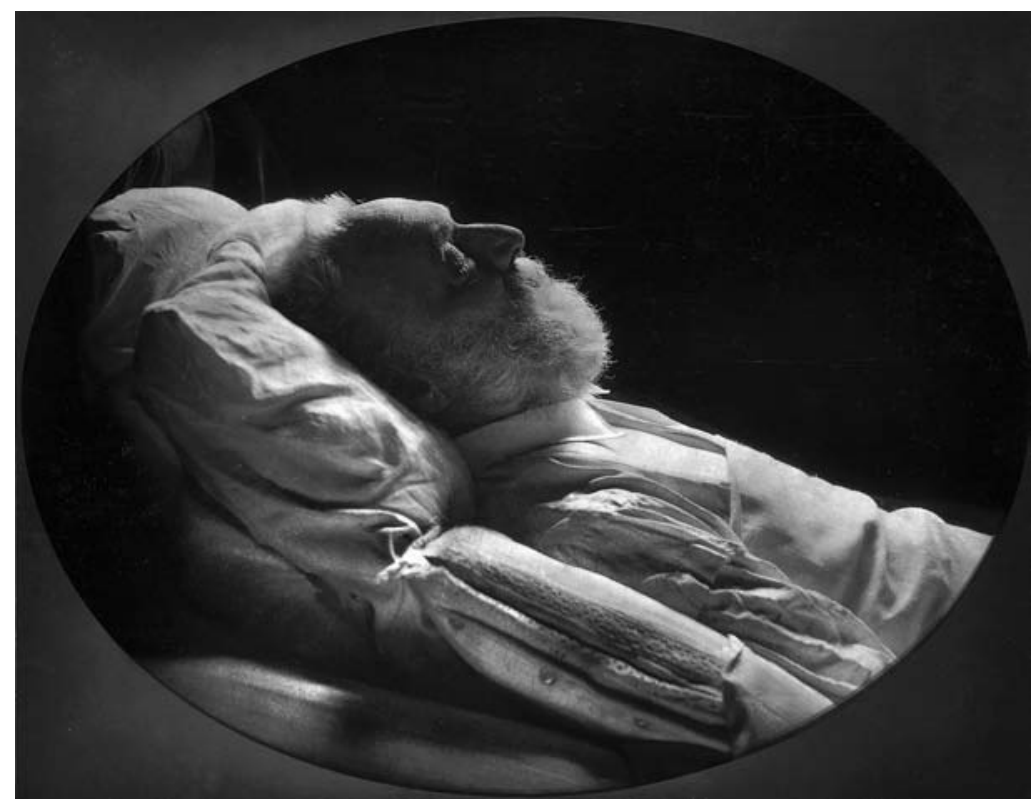

Figura 3.-Nadar. Victor Hugo en su lecho de muerte. 1885. J. Paul Getty Museum.

Continúa su relato con la preparación a la que se ha tenido que someter al cadáver para el acto:

Se había puesto de gala para esta ocasión, la gran recepción en la casa de la Muerte: el ritual requería vestir de negro, de impecable nuevo, los pliegues estrictos; el cuello blanco, la corbata, la pechera, los guantes violeta claro, todo con corrección irreprochable: la cuchilla evidentemente había pasado una última vez sobre su rostro de difunto. Por las luces de la ropa de cama, el almidonado de porcelana de la línea del cuerpo, el aspecto de cera de su cara, resaltaban más el negro opaco de su pelo, el cabello grueso, el bigote, y las cejas espesas se unían como una larga línea trazada sobre la parte alta de su nariz curvada ${ }^{14}$.

13 Gustave Doré sur son lit de mort, 1883, París, conservado en la Bibliothèque nationale de France (Bolloch 2002: 55)

${ }^{14}$ "On l'avait revêtu de sa toilette de gala pour cette unique, suprême réception chez la Mort: le rituel habit noir, lustré neuf, aux plis stricts; le col blanc, la cravate, le plastron, les gants violets 
Se describen aquí minuciosamente unos usos generalizados, según los cuales el fallecido es preparado por la familia para el tránsito final. No lo han vestido de ordinario — de diario-, como se realizaba en las imágenes del fallecido vivo, intentando simular un retrato del difunto en vida o dormido. Hablamos, por lo tanto, de la fotografía adoptada como una forma de inmortalidad, abierta ya al gran público, en su faceta democrática, donde el cadáver está presente de forma veraz. Como consecuencia, estamos ante una imagen que destierra definitivamente las visiones del difunto del pasado, a través de representaciones negadoras de la muerte, dando paso a un difunto en paz, yacente, una iconografía de muerto inmutable. Son imágenes tranquilizadoras, sencillas en su complejidad, que manifiestan el importante papel social que van a desempeñar como sustitutas del sujeto y como apoyo al dolor familiar ante el fin de la existencia.

En el texto Nadar deja evidencias de que el personaje era joven pero lo suficientemente adulto —unos 35 años (Ibid:: 150) — como para contar con otras fotografías que atestiguasen su presencia en el mundo. Por ello, es evidente que describe una imagen post mórtem como último testimonio del ser, su última fotografía. Se trata, pues, de una pieza cargada de gran fuerza, tanto sentimental como expresiva. Como señalaba John Berger a propósito del dibujo del rostro de su padre en el lecho de muerte: "la gente suele hablar de frescura de la visión, de ver algo por primera vez, pero la intensidad de ver algo por última vez es, creo yo, algo superior" (Berger 2007: 143).

Tras este primer fragmento, el autor continúa ofreciendo una descripción milimétrica de una construcción "modelo" que identifica a este tipo de retratos:

Los rasgos eran de una rectangularidad clásica, antigua. Sobre su lecho, un enorme crucifijo extendía sus brazos como para preservarlo, incluso en el más allá. El resto de la cama desaparecía bajo los montones de flores frescas cortadas y la habitación entera estaba de tal forma llena de flores, ramos suntuosos y coronas, que los pies tenían problemas para encontrar sitio por esas profusiones ${ }^{15}$.

La escena es arquetípica, aplicable a todo un archivo generacional de retratos fotográficos, inspirados en muchas ocasiones en composiciones pictóricas. La cruz en el lecho de muerte, las flores ornamentales y los brazos cruzados se convierten en una decoración y ordenación recurrentes, que en algunas ocasiones exponen conceptos más profundos que la mera escenificación formal de la imagen, como por ejemplo la religiosidad del difunto, su pureza de espíritu, etc. Son composiciones que, desarrolladas en la historia del arte desde la época medieval — tanto en escultura como en pintura-, encuentran en la fotografía una continuación representativa. De este modo,

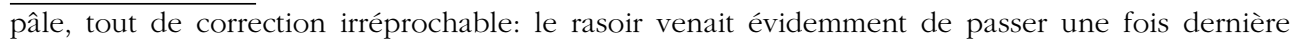
sur sa figure de mort. - Par les clartés de la literie, l'empois porcelaineux du linge de corps, la matité de cire du visage, se découpait le noir opaque des pilosités, cheveux drus, moustache fournie, sourcils épais se rejoignant comme une large barre tracée à l'encre au-dessus du nez courbé en rostre" (Tournachon 1900: 149).

15 "Les traits étaient d'une rectangularité classique, antique. Sur sa poitrine, un énorme crucifix étendait ses bras comme pour le préserver, encore et au-delà. Le reste du lit disparaissait sous les monceaux de fleurs frais coupées et la chambre entière était tellement jonchée de fleurs encore, bouquets somptueux et couronnes, que le pied avait peine à trouver place par ces profusions" (Ibid.: 150). 
se consolidan estructuras escenográficas cultivadas durante todo el arte del renacimiento y el barroco hasta recalar en las nuevas corrientes artísticas producidas en el siglo XIX, creándose un modelo fotográfico que se proyectará también durante todo el siglo XX. Estas composiciones se afianzan en el medio gracias a la democratización social del mismo y, por lo tanto, a la gran demanda del público. El propio Nadar usará este esquema en diferentes momentos, como por ejemplo en el retrato post mórtem que tomó de Michel Eugéne Chevreul en su lecho de muerte, imagen que reproduce el esquema ya clásico de una cruz sobre el pecho del difunto ${ }^{16}$.

Su estilo narrativo alcanza momentos de gran verosimilitud al describir situaciones que, aún dentro de un discurso historiado e incluso poético, no dejan de reflejar la dureza del trance:

Sí, cierto, él había sido muy querido, adorado por todos aquellos que lo rodearon; desde la antesala, las dos mujeres del servicio que, con gran dolor, nos recibieron, se retiraron inmediatamente, afligidas por las lágrimas. Otras mujeres —una, dos, tres, una familia entera-, todas igualmente vestidas con largos trajes, entraban aún silenciosamente una detrás de la otra, con sus ojos sombríos, llenos de lágrimas, y nos observaban con una desconfianza inquieta, recelosa, casi odiosa, como si nosotros fuéramos algo en esta muerte, como si nosotros viniéramos a arrancarles a su querido muerto...

Tuvimos problemas para obtener en aquella situación dos o tres palabras indispensables en francés: la casa entera era española, cosa que pudimos suponer por algunas palabras ahogadas, casi extinguidas por un piadoso respeto y bajo el aplastamiento...

La hermana de la caridad que permanecía arrodillada a los pies de la cama se levantó por fin y, sin darse la vuelta, desapareció. Nos pusimos con nuestro trabajo... ${ }^{17}$.

Por la descripción se desprende de una forma clara que se trataba de una familia acomodada, a pesar de que este tipo de encargos fueran solicitados por todas las clases sociales $^{18}$. Así se produce el gran proceso democrático del retrato, en el que cualquier individuo puede plasmar su presencia en el mundo, sin importar su nivel social (fig. 4). A continuación Nadar afirma que "Tuvimos problemas para obtener en

\footnotetext{
${ }^{16}$ Publicado en el grabado de Roy, M., "Chevreul sur son lit de mort", París Moderne, nº 3 , éditeur-344, s/f.

${ }^{17}$ "Oui, certes, il avait été aimé, adoré de tout ce qui l'entoura ; dès l'antichambre, les deux femmes de service qui, en grand deuil, nous reçurent, s'étaient aussitôt enfuies, étouffées par les larmes. - D'autres femmes encore, — une, deux, trois, une famille entière, — toutes uniformément vêtues de longs crêpes, survenaient silencieuses l'une après l'autre, et tous ces yeux sombres, brûlés par les larmes, nous regardaient avec une défiance inquiète, jalouse, haineuse presque, comme si nous étions, nous, pour quelque chose dans cette mort, comme si nous venions leur arracher ce cher mort...

Nous avions eu peine à obtenir dans cette confu-sion les deux ou trois paroles indispensables, en français : la maison entière était espagnole, ce que nous pûmes au moins supposer à quelques mots étouffés, presque éteints par un pieux respect et sous l'écrasement...

La sœur de charité qui était restée agenouillée au pied du lit se releva enfin et, sans s'être détournée, dísparut.

Nous nous mîmes à notre travail..." (Tournachon 1900: 150-151).

${ }^{18}$ Del mismo modo, aquéllos que habían gozado de los sistemas de representación artísticos no dudarán en hacer uso de este nuevo procedimiento para continuar con los viejos ideales del pasado. Sírvanos recordar aquí como ejemplo que el rey Óscar I de Suecia fue retratado en su lecho de muerte en el año 1859, introduciendo en la casa real una nueva modalidad de retrato: el fotográfico (Ahrén 2009: 102).
} 


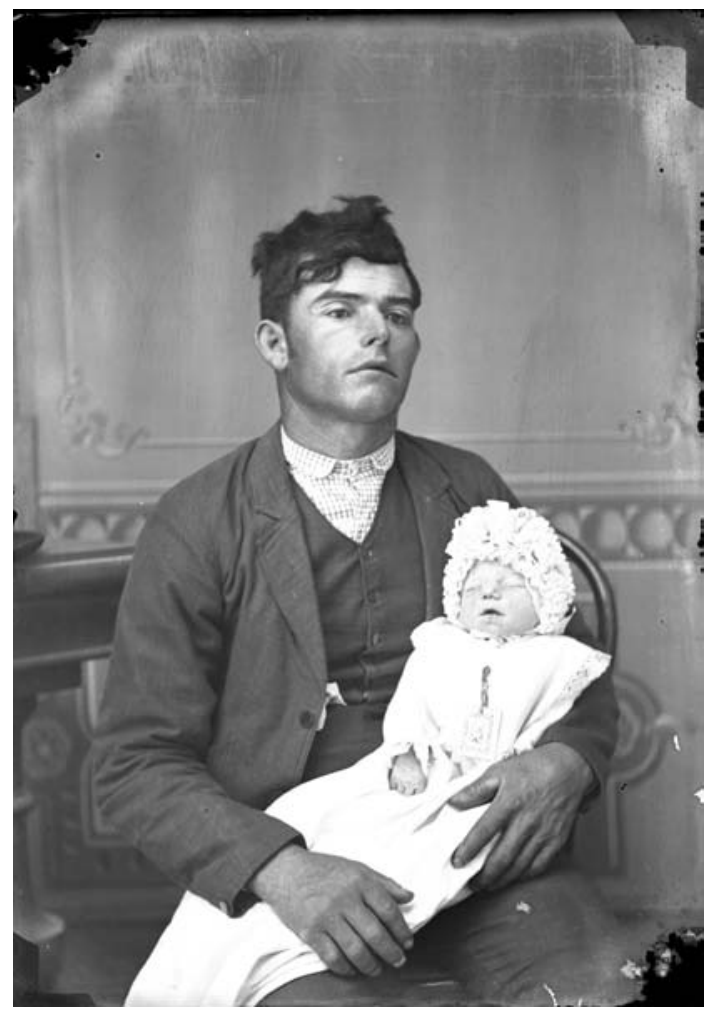

FIGURA 4.-Fernando Navarro. Retrato de padre y bebé difunto. 1895. Archivo general de la Región de Murcia. aquella situación dos o tres palabras indispensables en francés", palabras imprescindibles para que la familia pudiera indicar al fotógrafo cómo quería el retrato. Esto pone de manifiesto lo importante de la situación, pues se trata de representar al difunto según los criterios familiares. Hay que tener en cuenta que el fotógrafo adquiere un papel determinante en todo este ritual, y este hecho es fundamental porque va a ser él quien marque finalmente el concepto iconográfico de la representación, aunque evidentemente bajo los designios de la clientela.

Son instantes complicados puesto que los fallecidos en muchos casos eran enterrados el mismo día de su muerte - dependiendo de la situación del cadáver-, con lo que el fotógrafo tenía que desplazarse a la casa para facilitar y agilizar el proceso. Tal acontecimiento producía una intromisión en el ámbito familiar que alteraba todo el transcurso del velatorio, como se aprecia en la descripción realizada por el autor. Solo en el caso de que el difunto

fuera un niño se le solía trasladar al estudio, donde se improvisaba un retrato acorde con las demandas de la familia. En cualquier caso, el fotógrafo organiza estoicamente la composición adecuada al fin de la imagen. Es aquí donde el realizador adquiere un papel importante y preciso en estos momentos de tránsito. En este sentido, hay que recordar que, hasta la aparición de las funerarias y su asentamiento social, los familiares son los encargados de preparar el cadáver (como norma en el domicilio familiar), con lo que el lazo entre el vivo y el muerto sigue muy presente hasta su entierro, lo que hace aún más complejo este tipo de situaciones. Así pues, y a través de su presencia en el velatorio, el fotógrafo se convierte involuntariamente en uno de los actores principales de la escena, ya que interviene y condiciona indirectamente esa preparación, sobre todo en la configuración de la imagen final del difunto y, por lo tanto, del recuerdo que se va a tener de él con esa última escenificación (en este sentido, era normal que los familiares se dejaran aconsejar por la profesionalidad o cualidades del fotógrafo) (Bown 2009: 9). Se trata de crear una tramoya que, aunque fingida, prolongue el contacto con el ser desaparecido, al menos visualmente, rememorando lo vivido con él. Sea cual fuere la escenografía, nos encontramos con imágenes que evocan al ser querido, obras donde la belleza radica más en el recuer- 
do del individuo que en su presencia iconográfica, por lo que se repiten en muchas ocasiones las estructuras compositivas. Por lo tanto, la importancia de estas representaciones reside en su papel como conductoras de la memoria (Ewards 2009: 331).

Por otra parte, Nadar no puede dejar de lado su forma personal de interpretar los retratos, construyendo sus fotografías post mórtem con las mismas intenciones plásticas y conceptuales que cualquiera de sus otras imágenes (Heilbrun 1995: 35-58). En este sentido, sus obras siempre han sido producciones expresivas y no arquetípicas, y siempre han gozado de rasgos artísticos, alejándose conscientemente de la descripción simplista de Baudelaire cuando afirma que la fotografía es un arte narcisista que elimina lo trágico, lo elegante y lo delicado (Kuspit 2001: 144).

Tras lo expuesto, Nadar muestra su posición ante la compleja situación a la que los fotógrafos profesionales se enfrentaban cuando realizaban estas imágenes y afirma: «Si hay un penoso deber en la fotografía profesional, es la obligada sumisión a estos llamamientos funerarios "19. Reveladoras también son las palabras de André Adolphe Eugène Disdéri, que, al igual que Nadar, deja por escrito su incomodidad ante este tipo de ejercicios. Así, en el capítulo IV "Retratos después de la muerte" de su texto Información fotográfica necesaria para todos, de 1855, muestra concisamente su inquietud ante esta cuestión (pese a que destina el apartado a dar consejos sobre cómo representar estas composiciones): "Hemos realizado una multitud de retratos post mórtem; pero debemos confesar francamente que no lo hacemos sin repugnancia ${ }^{20}$. De esta apreciación se desprende, además, que el fotógrafo ha realizado innumerables retratos de esta naturaleza y que en 1855 era absolutamente corriente la producción de estas imágenes, lo que propició que a finales del siglo XIX cayeran en algunos casos incluso en la vulgaridad, hasta el punto de que se llegara a afirmar que, en ciertas ocasiones, se desenterraba a los cadáveres para hacerles la fotografía post mórtem, si no había dado tiempo a realizarla en el velatorio (Wickens-Feldman 2007: 431).

De todo ello se deduce claramente que, pese a ser una labor común que proporcionaba interesantes beneficios a los ejecutantes — se cobraban retribuciones más altas por este tipo de retratos, siempre justificadas por la escrupulosidad de los mismos-, no era una tarea agradable y que muchos de los que los hacían manifestaron públicamente su malestar ante este tipo de ejercicios. Incluso aquellos fotógrafos que declararon abiertamente que realizaban con cierto agrado este tipo de prácticas, dejaron de expresarlo, aunque no de practicarlo, por lo delicado de la situación. Lo cierto es que, con mayor o menor agrado, la aceptación de este tipo de encargos se daba por hecha. Cuando Nadar recibe el 22 de mayo de 1885 el breve mensaje "Viernes, 1h 30, venga cuanto antes", no duda en ir a casa de Víctor Hugo para fotografiarle en su lecho de muerte (Bolloch 2002: 116).

Tras ello, Nadar analiza de forma descriptiva este tipo de situaciones. Como buen observador y como buen fotógrafo, sabe plasmar todas las sensaciones y sentimientos que se experimentan ante un panorama tal, y de modo contundente afirma:

\footnotetext{
19 "S'il est un devoir pénible dans la photographie professionnelle, c'est l'obligée soumission à ces appels funéraires" (Tournachon 1900: 151).

20 "Nous avons pour notre part fait une multitude de portraits après décès; mais nous l'avouons franchement, ce n’est pas sans repugnance" (Disdéri 1855: 25).
} 
No es solamente recaer (como esta vez) en medio de dolores contra los cuales nada se puede (estallidos a veces tan crueles y desgarradores que, aunque ajenos, llegan a volverse propios sin que podáis libraros de ellos), sino también el sentir enseguida en su interior el recuerdo de los duelos personales, el hallar súbitamente despiertos los antiguos dolores que enmudecían, adormilados; las heridas mal cicatrizadas que reaparecen y vuelven a sangrar, lacerantes....

También es verdad que otras veces y ¡cuántas otras veces! nos hemos encontrado, por el contrario, bajo la parafernalia de los lutos y pésames oficiales, con la indiferencia más helada que el mismo cadáver, con la ávida codicia, única que permanece tras los restos mortales de aquel o aquella que acaba de caer, con las prolongadas impaciencias aliviadas al fin, los viles cálculos, la falsedad, la mentira ruin tanto tiempo mantenida - libres al fin, remunerados y con el esfuerzo de aplastar la alegría desbordante de la victoria conseguida—: argumento sobrecogedor contra la herencia.

Pero aquí, iqué lejos estábamos de esos lodos, cómo en la postración de esos dolores, cómo en los menores detalles de lo que nos rodeaba, qué bien sentíamos la atmósfera de ternura infinita, de adoración sin límites que persistía y palpitaba, cálida todavía - y más que nunca- en torno a este ser idolatrado, helado para siempre!...

¡Cuánto había merecido para ser tan querido, cuánta ternura había dado para que le devolviésemos tanto! ${ }^{21}$.

Así, Nadar deja entreabiertas cuestiones relacionadas con la importancia social de la fotografía como parte indispensable del duelo. Y es que su vulgarización propicia que en muchos casos se convierta en un elemento fijo de los rituales de defunción, hasta convertir el acto del "retrato" en uno de los pasos a seguir en la despedida del difunto, como algo protocolario que llega a ir más allá e, incluso, incorpora el retrato familiar con el muerto en la casa o en el propio cementerio. Este amor al fallecido hace que los allegados no duden en obtener para el recuerdo su última imagen, por triste e incómoda que pueda ser, y que pase a formar parte del álbum íntimo de la familia. Del mismo modo, este tipo de imagen cumple funciones testimoniales y notariales: en estos casos la familia no encarga la fotografía por amor al fallecido, como testimonio de su memoria, sino que la pieza se convierte en una certificación de su muerte.

Tras lo expuesto, Nadar pasa a construir una segunda parte del relato, que tiene como nexo de unión la historia anteriormente narrada del retrato post mórtem. En

${ }^{21}$ "Ce n'est pas seulement de tomber, comme cette fois, au milieu de douleurs contre lesquelles on ne peut rien, - explosions si cruelles parfois, si déchirantes, que bien qu'étrangères, elles arrivent à se faire vôtres sans que vous vous en puissiez defender; — c'est aussi de sentir bientôt s'évoquer en soi-même le souvenir des deuils personnels, de retrouver subitement réveillées les anciennes douleurs qui se taisaient, assoupies, - les plaies mal cicatrisées qui se ravivent et se remettent à saigner, lancinantes...

D'autres fois, il est vrai, et combien d'autres fois! n'avons-nous pas, tout à l'opposé, rencontré sous l'apparat des deuils et les regrets officiels, l'indifférence plus glacée que le cadavre lui-même, l'âpre cupidité, seule fervente après la dépouille de celle ou celui qui vient de tomber, les longues impatiences enfin soulagées, les vils calculs, la fausseté, le bas mensonge si longtemps poursuivis, - dégagés, rénumérés [sic] enfin et ayant peine à refouler la joie débordante de la victoire gagnée: — argument saisissant, contre l'héritage.

Mais ici, que nous étions loin de ces boues et comme dans la prostration de ces douleurs, comme dans les moindres détails de ce qui nous entourait, on sentait bien l'atmosphère de tendresse infinie, d'adoration efrénée qui persistait, palpitait chaude encore et plus que jamais autour de cet être idolâ-tré, glacé pour toujours!...

Que n'avait-il done pas valu pour être autant aimé, que n'avait il pas donné de tenderse pour qu'on lui rendit tant!. (Tournachon 1900: 151-152). 
esta ocasión describe la entrega de las copias fotográficas a la familia del difunto, para lo que toma como teatro su propio estudio de trabajo. Este acto, sencillo en apariencia, le da pie para reflexionar y manifestar algunas de sus inquietudes personales sobre el hecho fotográfico. En primer lugar narra el incidente que se produce con la entrega de las imágenes a la persona que se presenta en su local comercial como representante de la familia; situación que le sirve para resaltar la importancia que adquiere el retrato fotográfico en el siglo XIX:

Se nos pidió que aceleráramos las pruebas. En efecto, a la mañana siguiente, a primera hora, una dama con largos velos de crespón vino en busca de noticias, sin duda aquella que de entre las otras nos había hablado la víspera.

Cuando el empleado trajo las dos pruebas todavía mojadas, la dama se levantó el velo y las contempló, examinando sus queridas imágenes. Grandes lágrimas cayeron por sus mejillas, turbando sus ojos que el pañuelo no conseguía secar, hasta que — sofocada, nerviosa, angustiada - se retiró el velo para decirnos que quería llevarse esas pruebas tal cual estaban y que hubiese sido necesario obtener otras inmediatamente.

Solo había una opción: la dama se fue con las dos fotografías envueltas en papel secante ${ }^{22}$.

Pone así de manifiesto el rol que va a jugar la fotografía como herramienta precisa del recuerdo, de la presencia social y de la evocación íntima del desaparecido - de su posesión- Nadar, como Benjamin, sabía que la memoria no es un instrumento para explorar el pasado, sino más bien un medio (Benjamin 2010: 350). Precisamente, para el fotógrafo el objeto fotográfico adquiere dimensiones de dispositivo memorial, de conector que despierta tras su consulta los recuerdos: la simple contemplación del retrato hace aflorar la reminiscencia del ser. Como describe Geoffrey Batchen, cuando se nos invita a contemplar a un allegado u otra persona mirando una fotografía de un álbum familiar realizamos un acto de mantenimiento de la memoria. De manera que aunque una persona haya desaparecido, la contemplación de su imagen contribuye a no olvidarla: así, mirar nos ayuda a recordar (Batchen 2004: 10).

Del mismo modo, Nadar plantea la fotografía como una prótesis, como un sustituto conceptual del original desaparecido. Todo ello mediante la noción de que la posesión del retrato fotográfico, como objeto físico, presupone la propiedad del representado - no en vano, constituía su última presencia en este mundo-. Por lo tanto la imagen se convierte en una proyección palpable del difunto (el retrato fotográfico en general asume desde su nacimiento este papel sustitutivo de lo representado; un papel que va a mantener hasta su total vulgarización a finales del siglo XX, cuando la saturación social y los estragos de la imagen en sus múltiples variantes lo banalizan por completo).

${ }^{22}$ "On nous avait priés de hâter le tirage des épreuves. En effet, le lendemain matin, dès la première heure, une dame en longs voiles de crêpe venait aux nouvelles, celle sans doute parmi les autres qui la veille nous avait parlé.

Lorsque l'employé apporta sur une glace les deux épreuves encore mouillées, la dame releva son voile et les contempla avidement, penchée sur les chères images. De longues larmes coulaient sur ses joues, brouillant ses yeux que le mouchoir ne parvenait à étancher, - jusqu'à ce que suffoquant, nerveuse, affolée, elle s'en détourna enfin, rabattant son voile, pour nous dire que, telles quelles, elle avait à emporter ces épreuves et qu'on eût à en tirer d'autres immédiatement.

Il n'y avait qu'à s'incliner : la dame partit avec les deux photographies roulées dans le buvard" (Ibid.: 152-153). 
En la siguiente narración de Nadar, la viuda real se presenta en su estudio para solicitar las imágenes y comprueba que la persona que las ha recogido anteriormente no representaba a la familia en cuestión. La viuda, que se ha percatado de la presencia de la otra mujer, le exige con incomodidad: "Se entendía, señor, que usted entregaría estas pruebas solo a mí [...] Ella destacó, de forma obsesiva, la palabra 'solo'”, Las palabras de la mujer cobran especial relevancia a la luz del carácter mágico que tiene la fotografía en esa época, carácter que atribuye a la imagen - socioculturalmente- un significado más profundo que el de ser una simple representación de las facciones de un individuo.

Precisamente, una oscura escena de celos, escrupulosamente descrita a la manera de un retrato psicológico, es la base sobre la que Nadar asienta su posición ante el hecho fotográfico y la verdad del mismo. A continuación, tras las escenas del velatorio y la exposición de sus ideas personales sobre la iconografía post mórtem y su significado social, profundiza en su concepto de la verdad como fotógrafo y escribe:

¿Por qué me faltó la fuerza de olvidarme y renegar de mí para no ver más que aquella desgraciada que estaba ante mí, esperando su detención? ¿Me atreveré a proferir aquí que yo no había mentido nunca [...]? ¿Qué moral, qué Dios hubiesen reprobado esta vez mi mentira? [...] y, ¿cómo rechazar esta denuncia de yo mismo por mí mismo, cuando esta verdad conminadora estallase, cegadora? Un decreto mortal, ¿debe ser pronunciado dos veces? El suelo debajo de mí acababa de desplomarse... Penosamente, balbuceé:

- Señora, ha visto usted ya tanto que no me es posible mentirle... ${ }^{24}$.

Se trata de un alegato de verdad absoluta, de la imposibilidad del autor para mentir. Nadar se sitúa tras su declaración como un fotógrafo de la evidencia, puro y libre. Sus obras, sus retratos, son siempre reales, acordes con el natural, no hay manipulación posible en ellos. Todas las empresas fotográficas acometidas por él representan actuaciones veraces. Así, todas sus imágenes, desde las de catacumbas a las aéreas, son testimonios fidedignos de una realidad. El propio autor llega a afirmar:

La teoría de la fotografía puede aprenderse en una hora, y los elementos para practicarla, en un día [...]. Lo que no puede aprenderse es el sentido de la luz (un sentimiento artístico en relación con los efectos de la luminosidad variable y sus combinaciones), la aplicación de tal o cual efecto a los rasgos con los que se enfrenta el artista que llevas dentro [...]. Lo que puede aún menos aprenderse es la comprensión moral del sujeto: ese entendimiento instantáneo que te pone en contacto con el modelo, te ayuda a resumirlo, te guía hacia sus hábitos, sus ideas y su carácter, y te permite producir no una reproducción indiferente (cuestión de rutina o accidente, como la que cualquier ayudante de laboratorio podría conseguir) sino un parecido realmente convincente y comprensivo, un retrato íntimo [...] (en Tagg 2005: 72).

${ }^{23}$ "— Il est entendu, monsieur, que vous ne remettrez ces épreuves qu'à moi seule...

Elle avait appuyé, interprète obéissante, sur le mot — "seule" (Ibid.: 155).

${ }_{24}$ "Pourquoi me manqua-t-elle, la force de m'oublier, de me renier, moi, en ne voyant plus que la malheureuse qui était devant moi, attendant son arrêt? - Oserai-je donc proférer ici que je n'avais menti jamais [...] ? Quelle morale, quel Dieu eussent cette fois réprouvé mon mensonge ?

[...] et comment récuser cette dénonciation de moi-même par moi-même, quand cette vérité dont on me sommait éclatait, aveuglante ? Un arrêt mortel doit-il donc être absolument prononcé deux fois?

Le sol sous moi achevait de s'effondrer... - Péniblement, je balbutiai:

— Vous avez déjà trop vu, madame, qu'il ne m'est pas possible de vous mentir...” (Ibid.: 157). 
En este sentido, son muy apropiadas las palabras que Barthes vierte sobre Nadar en La cámara lúcida, que concluyen con la pregunta: "¿Cuál es, según vuestro parecer, el fotógrafo más grande del mundo?", a lo que responde: Nadar (Barthes 1999: 124). Afirma que este es un mediador de la verdad componiendo, por ejemplo, en la obra Ernestine Nadar una de las fotografías más bellas del mundo (Ibid:: 125).

Al final de su texto Nadar reflexiona sobre lo acaecido y nos transmite de nuevo el importante papel que la fotografía ha desempeñado en la segunda mitad del siglo XIX como elemento identificador de un individuo, consolidándose como un hecho transcendental de lo cotidiano y de la historia del arte. En este caso, bajo la idea sentimental del retrato como prolongación del ser, se lamenta por las faltas indirectamente infligidas a la viuda del fallecido:

Desde entonces —idesde hace tantos años! — cuántas veces habré recordado en París a aquella a quien involuntariamente hice tanto daño, ¡un mal que jamás —intolerable pensamiento! - podré reparar! Todo un mundo de recuerdos queridos, todo un pasado de juventud, de amor, de confianza, colapsado: lo agridulce en vez del recuerdo de los bellos días al lado del ser amado; el inexorable resentimiento, la indignación de la esposa traicionada, ultrajada; en lugar del respeto y del amor, el odio y el desprecio eterno. ${ }^{25}$.

Resulta claro que para Nadar la fotografía no es la representación vacía de un sujeto - un reflejo sin individualidad—, una modalidad iconográfica banal, sino un objeto que proyecta al ser concreto (cualidad intrínseca a todos sus ejercicios). De ahí los lamentos del autor ante la falta involuntariamente cometida, puesto que la entrega de la imagen significa para él la entrega de parte de la persona. En efecto, afirma que en sus retratos quedan capturadas siempre las cualidades psicológicas del personaje fotografiado, por lo que en ellos subyace de forma perenne la personalidad del individuo, parte de su yo. Como consecuencia de lo expuesto, sus composiciones sobrepasan el espacio simbólico de la identidad ideal y se adentran en conceptos significativos de lo real. Esto favorece que se conviertan, tras la desaparición del retratado, en representación física e ideológica del mismo, lo cual otorga a las imágenes un sentido icónico que despierta los sentimientos del ser y los recuerdos vividos con esa persona.

Así pues, en este último fragmento Nadar se presenta como un hombre íntegro, repleto de valores éticos que realiza su trabajo con honradez reflexiva, cualidades que le llevan a preferir la honorabilidad a otros aspectos materiales.

En suma, el texto en su totalidad se nos muestra como un documento de gran valor para la comprensión del retrato post mórtem en los años finales del siglo XIX —valor extensible a ejercicios realizados hasta bien entrado el siglo XX- y que refleja la personalidad de Nadar, una figura de renombre que no solo es un admirador de su época sino que es uno de sus actores principales, como fotógrafo y como investigador.

\footnotetext{
25 "Depuis, — depuis tant d'années déjà! — combien de fois l'ai-je revue dans notre Paris, celle à qui j'avais fait sans le vouloir tant de mal, un mal que jamais — intolérable pensée! — il ne me sera donné de réparer ! - Tout un monde de souvenirs chers, tout un passé de jeunesse, d'amour, de confiance, effondré : au lieu de la douceur amère mais attendrie au souvenir des beaux jours écoulés côte à côte avec l'être aimé, l'inexorable ressentiment, l'indignation de l'épouse trahie, outragée, — au lieu du respect, de l'amour, la haine, le mépris à jamais..." (Tournachon 1900.: 158).
} 


\section{BIBLIOGRAFÍA CITADA}

Ahrén, E. 2009. Death, Modernity, and the Body: Sweden 1870-1940. Rochester: University of Rochester Press.

Álvarez, T. 1998. "El arte ritual de la muerte niña". Revista Colombiana de Anestesiología 26: $377-382$.

Bann, S. 2009. "When I Was a Photographer: Nadar and History". History and Theory 4: 95-111.

Barthes, R. 1999. La cámara lúcida. Barcelona: Paidós Comunicación.

Batchen, G. 2004. Forget Me Not: Photography \& Remembrance. Nueva York: Princeton Architectural Press.

Bazin, A. 2006. ¿Qué es el cine? Madrid: Ediciones Rialp.

Benjamin, W. 2004. Libro de los pasajes. Madrid: Akal.

Benjamin, W. 2008. Obras I, 2. Madrid: Abada Ediciones.

Benjamin, W. 2010. Obras, IV, I. Madrid: Abada Ediciones.

Berger, J. 2007. El sentido de la vista. Madrid: Alianza.

Bolloch, J. 2002. "Photographie après décès: pratique, usages et fonctions", en Héran, E. (ed.), Le dernier portrait: 112-145. París: Réunion des Musées Nationaux.

Bown, N. 2009. "Empty Hands and Precious Pictures: Post-mortem Portrait Photographs of Children". Australasian Journal of Victorian Studies 2: 8-25.

Burgess, N. G. 1855. "Taking Portraits after Death". The Photographic and Fine-Art Journal 3: 80.

Burns, S. B. 2002. Sleeping Beauties II. Grief, bereavement and the family in memorial photography. American and European traditions. Nueva York: Ed. Burns Archive Press.

Cadava, E. 2012. "Nadar's Photographopolis”. Grey Room 48: 56-77.

Cadwallader, J. 2008. "Spirit Photography Victorian Culture of Mourning". Modern Language Studies 2: 8-31.

Campbell, D. 2004. "Horrific Blindness: Images of Death in Contemporary Media". Journal for Cultural Research 1: 55-74.

Creekmur, C. K. 1996. "Lost Objects: Photography, Fiction, and Mourning", en Bryant, M. (ed.), Photo-Textualities: Reading Photographs and Literature: 72-86. Delaware: University of Delaware Press.

Cuarterolo, A. 2002. "La imagen en el ritual póstumo. Fotografiar la muerte". Todo es Historia 424: 24-34.

Díez, J. L. 2004. "El retrato español del siglo XIX: el triunfo de un género", en Portús, J. (ed.), El retrato español. Del Greco a Picasso: 264-291. Madrid: Museo Nacional del Prado.

Disdéri, A. 1855. Renseignements photographiques indispensables à tous. París: Gaittet.

Draper, J. W. 1840. "On the Process of Daguerreotype, and its Application to Taking Portraits from the Life". London, Edinburgh, and Dublin Philosophical Magazine and Journal of Science: 217-225.

Ewards, E. 2009. "Photographs as Objects of Memory", en Candlin, F. y Guins, R. (eds.), The Object Reader: 331-342. Londres: Tylor and Francis Group.

Falomir, M. 2008. "El retrato en el Renacimiento. Prólogo a una exposición", en Falomir, M. (ed.), El retrato del Renacimiento: 17-21. Madrid: Museo Nacional del Prado. 
García Felguera, M. S. 2011. Els Napoleon. Un estudi fotográfic, Barcelona: Arxiu Fotográfic de Barcelona-Institut de Cultura de Barcelona i Imatge i Producció Editorial.

Gautrand, J. C. y Frizot, M. 1986. Hippolyte Bayard: Naissance de l'image photographique. Amiens: Trois Cailloux.

Guerra, D. F. 2010. “Con la muerte en el álbum. La fotografía de difuntos en Buenos Aires durante la segunda mitad del siglo XIX". Trace 58: 103-112.

Heilbrun, F. 1995. "Nadar and the Art of Portrait Photography", en Hambourg, M. M.; Heilbrun, F. y Néagu, P. (eds.), Nadar: 35-58. Nueva York: Metropolitan Museum of Art.

Johnson, C. 1999. "Photographic Materials", en Remini, R. (ed.), Gathering History: The Marian S. Carson Collection of Americana: 97-116. Washington: Library of Congress.

Kennel, S. 2007. "Bayard, Hippolyte (1801-1887)", en Hannavy, J. (ed.), Encyclopedia of Nineteenth-Century Photography: 122-125. Nueva York: Taylor \& Francis.

Kershner, R. B. 1998-1999. "Framing Rudy and Photography". Journal of Modern Literature 2: 265-292.

Krabben, A. 1998. "Onveranderlijk de eeuwigheid in", en Sliggers, B. (ed.), Naar het lijk. Het Nederlandse doodsportret, 1500-heden: 148-176. Zutphen: Walburg Press.

Krauss, R. 2002. Lo fotográfico. Por una teoría de los desplazamientos. Barcelona: Gustavo Gili.

Kuspit, D. B. 2001. "Fuego antiaéreo de los "radicales": la causa norteamericana contra la pintura alemana actual", en Wallis, B. (ed.), Arte después de la modernidad. Nuevos planteamientos en torno a la representación: 137-144. Madrid: Akal.

Lesy, M. 1973. Wisconsin Death Trip. London: Ed. Allen Lane.

Linkman, A. 2006. "Taken from Life: Post-mortem Portraiture in Britain 1860-1910". History of photography 30: 309-347.

Linkman, A. 2012. Photography and Death. Londres: Reaktion Book.

Martínez Artero, R. 2004. El retrato: del sujeto en el retrato. Barcelona: Intervención Cultural.

Marzal Felici, J. 2011. Cómo se lee una fotografía, interpretaciones de la mirada. Madrid: Cátedra.

Mitchell, W. J. T. 2005. What Do Pictures Want?: The Lives and Loves of Images. Chicago: The University of Chicago Press.

O’Connor, N. 2005. Déjalos ir con amor. México: Trillas.

Olguin, S. 2010. "Interactions with the Non-Human, Fetishism, Prosthesis and Postmortem Photography". Anamesa: An Interdisciplinary Journal 1: 98-108.

Rooseboom, H. 2011. "At the Turning Point: Reinier van der Lingen and the Tradition of Photographing one's own Children". Depth of Field 1: 93-100.

Rouillé, A. 1995. "When I Was a Photographer: The Anatomy of a Myth", en Hambourg, M. M.; Heilbrun, F. y Néagu, P. (eds.), Nadar. 107-114. Nueva York: Metropolitan Museum of Art.

Ruby, J. 1995. Secure the Shadow. Death and Photography in America. Londres: The MIT Press.

Sekula, A. 1981. "On the Invention of Photographic Meaning", en Goldberg, V. (ed.), Photography in Print: Writings from 1816 to the Present: 452-473. New Mexico: University of New Mexico Press. 
Smith, S. M. 1998. "Family Photographs and Kelly McKaig's Dreamworlds". A Journal of Women Studies 3: 98-111.

Sontag, S. 2008. Sobre la fotografía. Barcelona: Debolsillo.

Sturken, M. 1999. "The Image as Memorial: Personal Photographs in Cultural Memory", en Hirsch, M. (eds.), The Familial Gaze: 178-195. Londres: University Press of New England.

Tagg, J. 2005. El peso de la representación. Ensayos sobre fotografías e historias. Barcelona: Gustavo Gili.

Tournachon, G. F. 1858. Quand j'étais étudiant. París: M. Lévy frères.

Tournachon, G. F. 1900. Quand j'étais photographe. París: Éditeur Ernest Flammarion.

Wickens-Feldman, R. 2007. "Cosmestic and Family Photography", en Hannavy, J. (ed.), Encyclopedia of Nineteenth-Century Photography: 431-434. Nueva York: Taylor \& Francis.

Fecha de recepción: 23 de mayo de 2014

Fecha de aceptación: 23 de octubre de 2014 